The Challenges of School Libraries in Vocational Education in Tampere Region (Finland) - with EU-collaboration Project to the Future

\title{
Eija Hirvimäki
}

Head of Information Services

Valkeakoski Vocational College

Finland

Eija.hirvimaki@vsky.fi

\section{Anne Suoniemi}

Head of Information Services

Tampere Regional College

Finland

anne.suoniemi@tampere.fi 


\section{The Challenges of School Libraries in Vocational Education in Tampere Region (Finland) - with EU-collaboration Project to the Future}

It is not usual that there is a good library or learning centre in vocational institutes in Finland. Finland has a functional network of general libraries, but no national policy for school libraries. Nevertheless, some vocational institutes in Tampere Region have been able to realize a vision of the school library as an open learning environment; as a pedagogical tool and a source of innovations. AVOKI project - Developing of Open Learning Environments in Secondary Education in Tampere Region, is our answer to the biggest challenges of school libraries in vocational institutes. Connecting an EU-project, a professional and regional collaboration is the key to the following challenges:

1) Most of the vocational school libraries don't have an operational strategy

The reason why there isn't a strategy can be the unclear role of the school library. The school management isn't always interested in the most important task of the school library - supporting pedagogy by offering equipment for up-to-date education and material for various areas of profession. The management doesn't understand that the school library is a quality and success factor for the whole organization. Often there are not library professionals working at the school, too. If there is a librarian, she/he doesn't have always the ability to market the school library and make it visible. The biggest problems are:

- lack of interest

- resources: time, money and library professionals

2) Collaboration with teachers

The teachers and the librarian work in cooperation - still the new role of the library is often scary for the teachers. In Finland there are teachers or librarians, not teacher-librarians, working in school libraries. It takes time to assume this new partnership between teachers and librarians.

3) The school libraries as an open learning environment

The school libraries in vocational education should have a central location in the school. The premises should be easy to reach and pleasant to use. Interior and furniture should be up-to-date and comfortable. Some school libraries in AVOKI project didn't have an own room at all; they were situated in classrooms, teachers' rooms or in the corridor. Most of the 
school libraries don't have enough money to have furniture and computers and often there isn't expertise in school library planning, too.

4) Teaching information literacy skills to students and teachers

One of the biggest challenges of the school libraries in vocational education is teaching information literacy skills. The teachers and the librarian should work in cooperation to plan and draw up the contents of the training. Including the school library use and information literacy skills in the curriculum of every vocational subject strengthens the collaboration between the librarians and teachers. The teachers need information literacy skills, too. The librarians have an important role in vocational institutes in educating both teachers and students. The most important social challenges of the school libraries are:

- information society and lifelong learning

5) The computers and other technical equipment in the school libraries

The basic elements in the modern learning environment are the computers with good peripheral equipment. This enables the students to search, analyze and produce information in an open learning environment. In Tampere Region there were some vocational school libraries, which had only two old computers in use. Without a national policy for school libraries it's very difficult to have money for investments. AVOKI project has made it possible to build new school libraries in vocational education in Tampere Region.

6) The technical development and new innovations in education

The new electronic equipment: iPhones, iPads, smartboards, digital cameras etc. in the vocational school library can be a possibility but also a challenge to traditional school libraries with old material. All school libraries don't have money and professionals to use them (and train to use them!). The biggest challenges are:

- resources: not enough money

- technical training for using new technology

\section{Tampere College and AVOKI-project in Tampere Region}

Some years ago Tampere College started to build new kind of learning centers for their units. But first, what is Tampere College?

Tampere College is a vocational college and it is a part of Tampere Upper Secondary Education: 
- $\quad 4800$ certificate students

- 6000 adult students (specialist qualifications, further qualifications and short courses)

- $\quad 550$ staff members

- $\quad$ co-operation with firms and other employers

- $\quad$ preparatory education for immigrants for vocational training

- $\quad$ training for 100 occupations

- many study programmes (e.g. machinery and metal technology, electrical engineering, clothing, hairdressing, health and social services, business and administration, forestry etc.)

As Eija Hirvimäki stated it is not usual that there is a good library or learning center in the vocational educational institution in Finland. "The library doesn't belong to this type of vocational school". So there were some suspicions about libraries and their building project. That's why we designed our libraries to the needs for the vocational education.

At moment we have Learning Center in every unit of Tampere College. Our first learning centers were:

- Hervanta opened in February 2007

- very modern, IT-library, learning center and mediatheque

- many study programmes, machinery and metal technology is the biggest field

* Pyynikki completed and opened in March 2008

- same function model as in IT- library of Hervanta

- many study programmes, among other things electrical engineering and clothing

These libraries were built from the beginning and they were also the starting points for AVOKI project. Very fast we got good feedback from our services. Our students and teachers started to use the library services eagerly. The functional model is simple: we connected the traditional school library and the modern learning environment. There are sufficiently computers and other IT equipment in our libraries. Useful softwares, the same which are used in the education/teaching make possible to the students doing their tasks in the library as well. The library is rightly a modern learning environment. The teachers can step out from the classroom or the workshop and come to the beautiful library and arrange their teaching in another ways.

We borrow laptops (=portable computers), digital cameras, video cameras, tabletts etc. These objects have been catalogued to our library system so we don't have only books or printed material in our database.

Our experiences were so good and the library services received praise and positive envy. That's why we decided to request money to the project from the European Union. We wanted to spread this good practice also for the other educational institutes in Tampere Region and to create in the same time the model of good Learning Center in Finland and perhaps still wider, outside borders of the country. The European Union Structural Funds and The Council of Tampere Region were keys of the solution. This project was also quite new kind of project to our financier. 


\section{What is AVOKI?}

AVOKI - Development of Open Learning Environment in Secondary Education in Tampere Region 2009 - 2011

* EU-investment project, European Union Structural Funds and The Council of Tampere Region (The Council makes a decision on the financing at a national level)

* Total financing 889500 Euros, of which local, municipal funding is 249060 Euros

* hands on - program

* Tampere City was the project leader, 5 partners from Tampere Region participated in this project and one of them was Eija Hirvimäki's institute from Valkeakoski

The other big actor was Pirkanmaa Vocational Institute. They didn't have own libraries at all before AVOKI project but now they have a good start for developing libraries or learning centers. High schools (upper secondary schools) were also along.

AVOKI project is our answer to the demands of Information Society and a functional model for developing school libraries.

With the help of AVOKI, we improved and developed the libraries and IT equipment at schools by providing students with
* computers and other hardware
* different software
* network services
* databases
* materials: books and DVDs etc. and above all
* by planning open learning environment at schools

If there was a library or another suitable room at school, we transformed it into an open, innovative and multipurpose learning center; we made it into a living room for students.

In this project we reformed altogether 15 different rooms for students. Here are some examples:
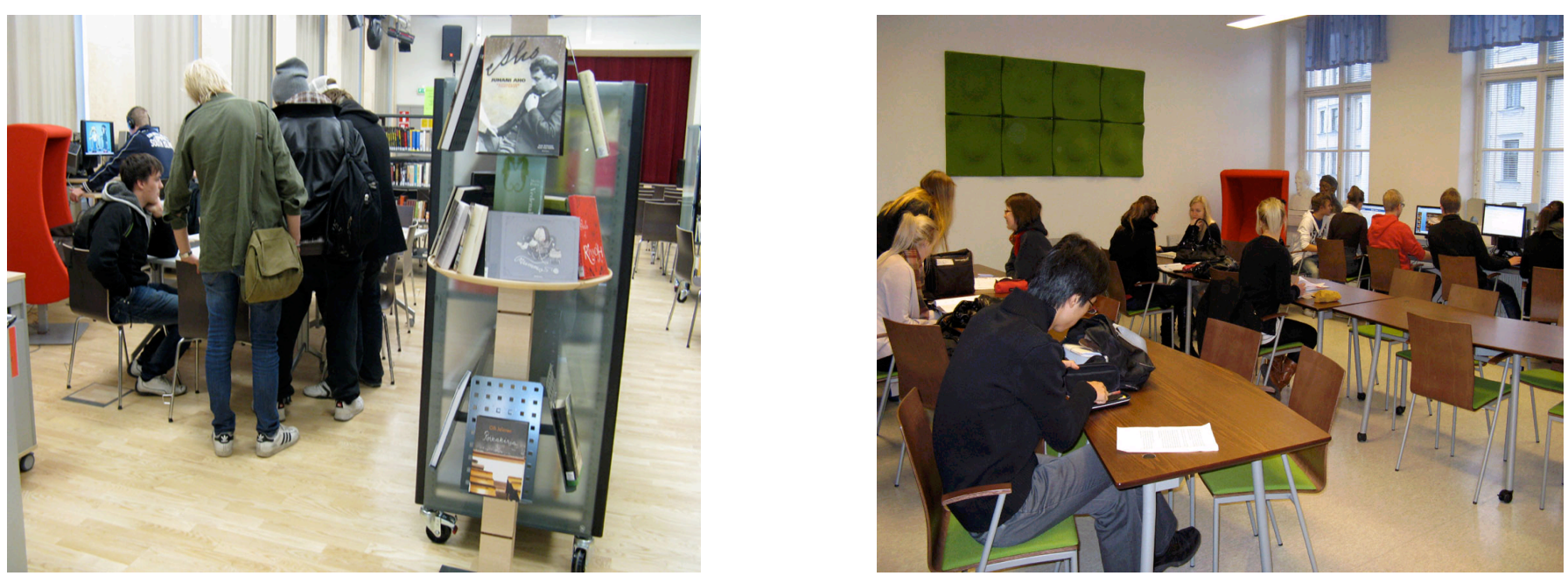


\section{Why do we want to develop our school libraries or learning centers in Tampere Region?}

\section{What were the objectives of AVOKI-project? We didn't want to buy things only because of those things, we had more profound (deeper) purpose.}

* to promote media education, e-learning and information skills teachers and students alike

The teachers are in central position because they govern their students and they are naturally experts at their own subject. But teachers need continuing updating of information searching and new media world (and of course the same thing concerns also librarians. And they must learn more to utilise different kind of information resources in their teaching. In different investigations have been found out that the teachers can't utilise enough the resources of Internet in their teaching. However there is lot of good material in Internet for teaching and education and a lot of money has been spent for that purpose.

We also think very easily that the young people already know everything about information technology and they are much wiser than we adults are in this new kind of information society because the young have grown up to it, Recently I heard funny comparison: The young are diginative, we adults are digi-immigrants.

This is true but not the whole truth. The young people need the guidance of adults. E.g. everyone is able to use Google but only a few know how it really works and how deceiving it is. The young should understand that the Information society does not only mean playing and entertainment from one day after another. The young can open the door to the world of knowledge and lifelong learning but we adults have to guide them. It is worrying that the utilization of new media is bad/weak/poor. The restlessness and impatience of some young has also increased, What are the reasons of this development?

STILL

* to include information skills into the school curricula and different vocational subjects $\rightarrow$ co-operation with teachers and librarians is extremely important, we are looking for good resources from Internet or acquire different kind of digital materials. Our task is to open up and tell about our services and interesting possibilities and internet resources which can be useful in teaching and learning.

* to promote the development of virtual and interactive network services and their educational contents (e.g. Netlibray TOKI is a common database of whole secondary level schools in Tampere), with the help of the financing of AVOKI project TOKI extended into the regional library database of educational institutions in Tampere Region ( http://toki.verkkokirjasto.fi).

* to acquire good collections which support learning and take into consideration different groups of students and different point of views in learning, We don't want to forget the books or literature altogether. But the electric materials are more and more important. And our management emphasises electronic operational culture/environment (electronic things) very much but our teachers are not always 
able to stay behind. They want to use the printed material because it is simple and fast.

* to strengthen co-operation between project partners and create common functional models

* to create comfortable and innovative facilities for students. The student is the most important for us, she/he is in the centre.

\section{Results}

* We have now a model of good and multipurpose mediatheque

* The management and the teachers of our schools/institutes have understood much better the meaning of good school library, they see it more as open learning environment which really is connected with education and teaching, the appreciation has increased

* Our students have been happy about new places of learning

* The school libraries are taken into consideration in ICT strategies at schools/educational institutes and in curricula of the information skills

* The co-operation has increased between different actors

Pirkanmaa Vocational Institute and Tampere College are going to combine next year 2013, it will be Tredu Tampere Vocational Education and it will be one the biggest vocational educational institutions in Finland. AVOKI served this purpose well. The information services enlarge at vocational education at least in Tampere Region. I believe and if it depends on me.

\section{Challenges}

How to maintain a good level of IT equipment at our learning centers, money is needed

- More skills and knowledge are needed both for teachers and for librarians

* How to stay up to date in this world

How to respond to all the needs, the demand increases all the time

We should produce these services with very small staff

\section{Contact Information:}

\section{Eija Hirvimäki}

Head of Information Services

Valkeakoski Vocational College

Finland

Eija.hirvimaki@vsky.fi
Anne Suoniemi

Head of Information Services

Tampere Regional College

Finland

anne.suoniemi@tampere.fi 